\title{
Kemampuan Guru Sekolah Dasar dalam Mengembangkan Soal Tes Berpikir Kritis Berbasis ESD
}

\section{R Rakhmayani1*, G Hamdu²}

1,2 Jurusan Pendidikan Guru Sekolah Dasar, Universitas Pendidikan Indonesia Kampus Tasikmalaya, Tasikmalaya, Indonesia

\section{ART ICLE IN F O}

Article history:

Received March 09, 202

Revised April 15, 2021

Accepted June 11, 2021

Available online July 25, 2021

Kata Kunci:

kemampuan, guru, soal tes, ESD

Keywords:

Ability, Teacher, Test

Questions, ESD

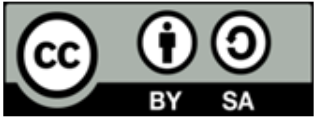

This is an open access article under the CC BY-SA license.

Copyright $(2021$ by Author. Published by Universitas Pendidikan Ganesha.

\section{A B S T R A CT}

ESD (Educational Sustainable Development) is a UNESCO program in education so that in the next era, students can be responsible for overcoming problems related to the environment, economy and society. To support the achievement of the ESD program, critical thinking is needed. Assessment using critical thinking test questions is believed to be able to develop students' higher-order thinking skills. However, teachers in schools have not been able to make appropriate questions. The purpose of the study was to analyze the ability of elementary school teachers' ability to develop ESD-based critical thinking test questions and their causal factors. This type of research is qualitative. The primary data sources include 7 teachers for grades $I V, V$, and VI in different primary schools. Sources of supporting data in the form of documents written test questions. The instruments used are interview guidelines, observation sheets, documentation study sheets and questionnaire sheets. Data were collected by interview and documentation techniques. The technique used to analyze the data is descriptive qualitative and quantitative analysis. The study results show that 6 teachers have made critical thinking test questions but not maximized, and 1 other has. This is because it is challenging to determine KKO (active verbs) and choose a stimulus. In addition, related to ESD-based learning, the concept has not been understood, but the implementation in the field has been realized. So it can be concluded that the level of ability of elementary school teachers in developing ESD-based critical thinking test questions is still low, and there is a need for coaching and training.

\section{PENDAHULUAN}

Sekolah menjadi agen utama dalam mendukung pembangunan berkelanjutan (Darmaji et al., 2019; Kostiainen et al., 2018). Pada implementasinya sekolah harus membiasakan siswa untuk menghemat energi dan air (reduce), peduli terhadap lingkungan dengan cara menjaga kebersihan, membuang sampah pada tempatnya serta melestarikan lingkungan sekolah (recycle and reuse) juga disater risk management (Pearce et al., 2020; 
Wijayanti \& Christian Relmasira, 2019). Program ESD (Educational Sustainable Development) yang diterapkan secara terus-menerus di sekolah dasar mampu untuk mengembangkan literasi lingkungan dalam diri siswa (Ferrer-Estévez \& Chalmeta, 2021; Oh \& Park, 2017). Untuk dapat membentuk karakter siswa yang perduli pada lingkungan maka seorang guru harus dapat menerapkan prinsip-prinsip ESD dalam pembelajaran (Didham \& Ofei-Manu, 2020; Ortega-Sánchez et al., 2018). ESD secara umum dapat dipahami sebagai "Pendidikan yang memberdayakan siswa supaya dapat mengambil keputusan berdasarkan informasi yang mereka peroleh serta senantiasa bertindak secara bertanggung jawab terhadap lingkungan, ekonomi dan masyarakat untuk generasi sekarang dan masa depan dengan selalu menghormati keragaman budaya yang ada" (Ferrer-Estévez \& Chalmeta, 2021; Wijayanti \& Christian Relmasira, 2019). Sehingga dituntut sekali untuk guru menguasai konsep ini untuk diajarkan kepada siswa. Sejalan dengan hal tersebut, saat ini sekolah-sekolah di Indonesia sudah menerapkan Kuikulum 2013 (Subagia \& Wiratma, 2016; Wulandari, 2020). Kurikulum 2013 mengalami revisi pada tahun 2017. Hal tersebut dikarenakan pelaksanaan pembelajaran harus memuat beberapa kompetensi meliputi $4 C$ (creative, critical thinking, communicative dan collaborative), literasi, PPK (Penguatan Pendidikan Karakter) dan HOTS (High Order Thinking Skiils) (Handayani \& Amirullah, 2019; Lestari, 2018). Keterampilan 4C ini sebagai keterampilan yang harus dikuasai oleh siswa supaya dapat berkompetisi pada abad 21. Dari beberapa keterampilan tersebut, paling harus dimiliki oleh siswa yaitu berpikir kritis karena merupakan dasar atau modal awal untuk dapat mengembangkan keterampilan berpikir tingkat tinggi lainnya (Rahmat et al., 2020; Yamin et al., 2020). Banyak sekali permasalahan lokal maupun global yang menuntut seseorang untuk dapat kritis dalam memilah informasi yang dijadikan sebagai sumber akurat supaya dapat dipertanggung jawabkan kebenarannya (Agusti et al., 2019; Boso et al., 2021). Oleh sebab itu guru sebagai seorang pendidik diharapkan dapat membantu dalam mengembangkan keterampilan berpikir ktiris siswa. Dengan demikian fokus penelitian ini berkaitan dengan kompetensi berpikir kritis.

Namun berdasarkan peringkat Programme for International Studen Assessment (PISA) dan Trends in International Mathematics and Science Study (TIMSS) keterampilan berpikir tingkat tinggi (High Order Thingking Skills) negara Indonesia tergolong rendah dibandingkan negara lain (Lia, 2015; Nugrahanto \& Zuchdi, 2019). Hal tersebut mampu menempatkan posisi Indonesia menjadi urutan keempat dari 72 negara dalam hal prestasi siswa dibandingkan tahun 2012 (Fenanlampir et al., 2019)Dalam rangka mengembangkan keterampilan berpikir kritis siswa, guru dapat menggunakan Taksonomi Bloom sebagai landasannya. Guru memberikan pertanyaanpertanyaan yang berkaitan dengan pemikiran tingkat tinggi (high order thinking skills) meliputi analisis, sistesis dan mengevaluasi (Khan \& Masood, 2015; Narayanan \& Adithan, 2015). Oleh sebab itu untuk menunjang keprofesionalannya sebagai guru maka tugas guru bukan hanya mendidik dan membimbing saja pada saat pembelajaran tetapi harus mampu untuk melakukan penilaian kepada siswa (Ambussaidi \& Yang, 2019; Monica et al., 2011). Salah satunya dengan terampil membuat soal tes tertulis yang baik dan tepat untuk digunakan.

Namun pada pelaksanaanya di lapangan masih banyak guru-guru sekolah dasar yang masih kesulitan dalam pembuatan dan pengembangan soal tes tipe HOTS (Pratama \& Retnawati, 2018; Sagala \& Andriani, 2019). Hal ini dibuktikan dengan hasil penelitian yang dilakukan oleh Winarti et al (2021) bahwa "kemampuan guru dalam membuat soal berdasarkan kurikulum 2013 berada pada kategori cukup, hal ini dikarenakan guru mengalami kesulitan membuat soal HOTS dan menetukan perbedaan tingkat kognitif dari suatu pertanyaan". Sejalan dengan dalam menyusun soal tes berpikir tingkat tinggi, sebagian guru belum berhasil. Sebagian guru soal pada kategori tingkatan C3 (penerapan) sudah dianggap sebagai soal tes berpikir tingkat tinggi. Artinya, siswa belum dibiasakan dengan soal-soal yang mengukur HOTS (Rahaju et al., 2020). Penilaian hasil belajar siswa merupakan kegiatan menghimpun dan mengolah informasi berdasarkan hasil belajar siswa dengan tujuan untuk mengetahui perkembangan pembelajarannya serta untuk menyimpulkan hasil pencapaian pembelajaran siswa (Putra \& Sujana, 2020; Suparmi, 2019). Salah satu alat penilaian yaitu berupa tes. Tes didefinisikan sebagai cara atau prosedur yang dapat digunakan untuk mengukur dan menilai dalam bidang Pendidikan (Chang \& Kang, 2018; Psaradakis \& Vávra, 2020). Seorang pendidik harus memiliki kemampuan dalam menilai hasil belajar siswanya (Kadir, 2015; Li et al., 2021).

Tes yang sering digunakan oleh guru yaitu berupa tes tertulis berbentuk pilihan ganda dan uraian. Dalam pelaksanaanya tes tertulis dilakukan dengan cara menjawab soal ujian pada kertas ujian secara tertulis, baik dengan tulisan tangan ataupun komputer (Daniels \& Gierl, 2017; Yusuf, 2017). Tes ini dapat dikembangkan sesuai dengan keterampilan yang akan diukur yaitu keterampilan berpikir kritis dengan indikatornya meliputi keterampilan analisis, sintesis, memecahkan masalah, menyimpulkan dan evaluasi (Juditya et al., 2020; Taimur \& Sattar, 2018). Indikator-indikator tersebut termasuk ke dalam kriteria HOTS. Untuk dapat mengetahui HOTS pada siswa maka diperlukan sebuah penilaian yang dapat mengukur kemampuan tersebut. Sejalan dengan itu, memberikan pertanyaan terbuka dapat melatih siswa untuk berpikir lebih luas) (Nada et al., 2018; Suratmi, Laihat, 2020). Kurangnya kemampuan guru dalam mengenbangkan soal tipe HOTS kemungkinan dapat atasi dengan melakukan pelatihan dalam penyusunan soal HOTS untuk menunjang kemampuan pedagogik seorang guru. Tujuan penelitian ini yaitu menganalisis kemampuan guru sekolah dasar dalam mengembangkan soal tes berpikir kritis berbasis ESD serta faktor penyebabnya. vHasil penelitian ini diharapkan dapat memberikan rekomendasi berkaitan dengan 
memberikan contoh yang tepat bagi guru SD dalam mengembangkan soal tes yang dapat mengali kemampuan berpikir kritis berbasis pada $E S D$.

\section{METODE}

Penelitian ini menggunakan metode deskriptif kualitatif. Metode ini menggunakan alur induktif yaitu penelitian diawali dengan penjelasan suatu proses atau peristiwa sehingga di akhir dapat ditarik generalisasi sebagai suatu kesimpulan (Yuliani, 2018). Sumber data utama dalam penelitian ini melibatkan 7 guru kelas tinggi, dengan rincian 4 guru mengajar di kota Tasikmalaya, 2 guru mengajar di kabupaten Tasikmalaya dan 1 guru mengajar di kabupaten Cirebon. Pemilihan guru ini didasarkan pada kesesuaian $K D$ mata pelajaran yang berkaitan dengan soal tes berbasis $E S D$, di samping itu juga didasarkan pada pemilihan tingkat berpikir kritis yang merupakan kategori berpikir tingkat tinggi ditinjau dari Taksonomi Bloom yang diajarkan di kelas tinggi. Adapun sumber data pendukung yaitu soal-soal tes tertulis kelas IV, V dan V. Instrumen yang peneliti gunakan yaitu pedoman wawancara, lembar observasi, lembar studi dokumentasi dan lembar kuesioner. Pedoman wawancara yang dibuat oleh peneliti akan ditanyakan kepada guru dengan pertanyaan sebanyak 26 butir. Lembar studi dokumentasi yaitu dokumen-dokumen yang hendak diteliti berupa soal-soal. Lembar kuesioner berisi tentang pertanyaan karakteristik identitas narasumber dan pertanyaan tertulis mengenai hal-hal yang diketahui oleh responden mengenai pengembangan soal tes. Instrumen-isntrumen tersebut divalidasi secara FGD dan oleh expert judgement sebagai validato.

Berdasarkan pandangan tersebut peneliti mengumpulkan data menggunakan wawancara, expert judgement (penilaian ahli), dan mengumpulkan dokumen. Pertama-tama peneliti menyusun kisi-kisi dan instrumen wawancara yang memuat 26 pertanyaan serta kisi-kisi lembar validasi soal baik pilihan ganda dan essay, kemudian dilakukan expert jugdement (penilaian ahli) untuk memvalidasi instrumen wawancara. Tujuan penilaian ahli yaitu untuk menguji kelayakan instrumen yang telah dirancang. Selanjutnya Wawancara dilakukan oleh peneliti kepada guru sekolah dasar yang telah ditentukan. Wawancara dimaksudkan untuk dapat mengidentifikasi masalah yang berhubungan dengan perencanaan dan penerapan soal tes tertulis yang ada di sekolah. Setelah itu, peneliti mengumpulkan dokumen berupa soal-soal tes yang ada di sekolah tersebut untuk dianalisis menggunakan kisi-kisi lembar validasi soal.

Tabel 1. Kisi-kisi instrumen wawancara

\begin{tabular}{|c|c|c|}
\hline \multicolumn{2}{|c|}{ Fokus Penelitian } & Indikator \\
\hline $\begin{array}{l}\text { Permasalahan } \\
\text { (problem } \\
\text { related) }\end{array}$ & $\begin{array}{l}\text { 1. } \text { Perbedaan tes } \\
\text { tertulis yang dilihat } \\
\text { dari kebijakan } \\
\text { persepsi atau bahkan } \\
\text { dengan praktiknya }\end{array}$ & $\begin{array}{l}\text { a. Policy synthesis } \\
\text { Memahami kebijakan soal tes tertulis dalam kurikulum } \\
\text { 2013. } \\
\text { b. Field portrait } \\
\text { Menjelaskan penerapan penilaian menggunakan soal tes } \\
\text { tertulis di sekolah dasar. } \\
\text { c. Perception poll } \\
\text { Memaparkan pendapat tentang kebijakan Kurikulum } 2013 \\
\text { yang menerapkan penilaian menggunakan soal tes tertulis. } \\
\text { Perception poll } \\
\text { 1. Fakta tentang tes tertulis tematik di sekolah dasar. } \\
\text { 2. Pengembangan tes tertulis yang sudah ada sebelumnya } \\
\text { a. Field portrait } \\
\text { 1. Kesesuaian tes tertulis dengan keterampilan berpikir } \\
\text { siswa. } \\
\text { 2. Kesesuaian soal tes tertulis dengan indikator } \\
\text { pembelajaran. } \\
\text { Kesesuaian soal tes tertulis dengan tujuan } \\
\text { pembelajaran. } \\
\text { SWOT analysis } \\
\text { Melalui proses }\end{array}$ \\
\hline
\end{tabular}

Konteks 5. Relevansi kebijakan (context kurikulum dengan related) sekolah a. Policy synthesis

1. Menjelaskan kebijakan sekolah yang relevan dengan kurikulum 2013.

2. Menjelaskan peraturan sekolah dalam menerapkan penilaian menggunakan soal tes tertulis.

$\begin{array}{lr}\text { 6. } & \text { Gambaran } \\ \text { penilaian } & \text { yang }\end{array}$

\section{b. Field portrait}

Menggunakan gambaran praktik di lapangan (pedoman 


\begin{tabular}{|c|c|c|}
\hline \multicolumn{2}{|c|}{ Fokus Penelitian } & Indikator \\
\hline & terjadi sekarang ini & khusus, sarana prasarana, rubrik). \\
\hline & 7. Perasaan & a. Perception poll \\
\hline & Stakeholder & 1. Mengetahui pendapat tentang pembelajaran berbasis \\
\hline & $\begin{array}{lr}\text { terhadap } & \text { kondisi } \\
\text { sekolah } & \text { (demografi } \\
\text { sekolah) }\end{array}$ & $\begin{array}{l}\text { ESD dapat meningkatkan kompetensi berpikir kritis } \\
\text { 2. Mengetahui pendapat tentang kesulitan dalam } \\
\text { menerapkan pembelajaran berbasis ESD. }\end{array}$ \\
\hline & 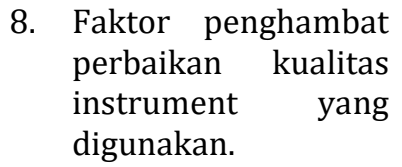 & $\begin{array}{l}\text { a. SWOT analysis } \\
\text { Melalui proses FGD (Focus Group Discussion) }\end{array}$ \\
\hline & $\begin{array}{l}\text { 9. Batasan solusi yang } \\
\text { dilakukan. }\end{array}$ & $\begin{array}{l}\text { a. SWOT analysis } \\
\text { Melalui proses FGD (Focus Group Discussion) }\end{array}$ \\
\hline & $\begin{array}{ll}\text { 10. Sejauh mana } \\
\text { stakeholder } & \\
\text { menganggap } & \\
\text { permasalahan } & \text { ini } \\
\text { membetuhkan } & \\
\text { perbaikan. } & \end{array}$ & $\begin{array}{l}\text { a. Perception poll } \\
\text { 1. Permasalahan yang dialami terkait tes tertulis tematik } \\
\text { berbasis ESD. } \\
\text { 2. Solusi permasalahan yang ditawarkan perihal tes } \\
\text { tertulis tematik berbasis ESD. }\end{array}$ \\
\hline $\begin{array}{l}\text { Kebutuhan } \\
\text { (needs } \\
\text { related) }\end{array}$ & $\begin{array}{l}\text { 11. Solusi potensial } \\
\text { terkait tes tertulis } \\
\text { menurut stakeholder. }\end{array}$ & $\begin{array}{l}\text { a. Perception poll } \\
\text { Ide atau gagasan tes tertulis tematik berbasis ESD. }\end{array}$ \\
\hline
\end{tabular}

Teknik yang digunakan untuk menganalisis data yaitu analisis deskriptif kualitatif dan kuantitatif. Pada penelitian ini menggunakan teknik model Miles dan Huberman. Langkah-langkah teknik analisis model ini yaitu data collection, data display, conclusions: drawing/verifying dan data condensation (Miles et al., 2014). Selanjutnya uji keabsahan penelitian ini dilakukan melalui pengamatan dan triangulasi.

\section{HASIL DAN PEMBAHASAN}

\section{Hasil}

Penentuan responden dilakukan melalui pengambilan data berdasarkan identitas berdasarkan tempat mengajar, usia dan jabatan/golengan dari guru SD. Identitas ini diperoleh dengan mengisi isian melalui google form terkait identitas serta karakteristik responden yang terlibat dalam penelitian ini. Berdasarkan hasil analisis data adapun pemahaman guru mengenai penilaian dalam kurikulum 2013 disajikan pada tabel 1.

Tabel 1. Pemahaman guru mengenai penilaian dalam kurikulum 2013, ESD dan ketarampilan berpikir kritis

\begin{tabular}{cccc}
\hline Guru & $\begin{array}{c}\text { Pemahaman mengenai penilaian } \\
\text { dalam kurikulum 2013 }\end{array}$ & $\begin{array}{c}\text { Pemahaman } \\
\text { mengenai konsep ESD }\end{array}$ & $\begin{array}{c}\text { Pemahaman mengenai } \\
\text { keterampilan berpikir kritis }\end{array}$ \\
\hline A & Sangat Baik & Cukup & Baik \\
B & Sangat Baik & Baik & Sangat Baik \\
C & Kurang & Baik & Baik \\
D & Cukup & Kurang & Cukup \\
E & Baik & Kurang & Baik \\
F & Sangat Baik & Cukup & Sangat Baik \\
G & Baik & Cukup & Cukup \\
\hline
\end{tabular}

Sejalan dengan itu hasil analisis data, kebijakan pemerintah terkait kurikulum 2013 yang menerapkan penilaian menggunakan soal tes tertulis disetujui oleh 7 guru dan menginginkan supaya tetap diadakan. Di masing-masing SD tempat 7 guru mengajar sendiri soal tes tertulis yang diberikan kepada siswa bentuknya sama berupa soal pilihan ganda, isian singkat dan uraian. Untuk pelaksanaanya juga sama, PTS (Penilaian Tegah Semester) dilaksanakan setiap 3 bulan sekali dan PAS (Penilaian Akhir Semester) dilaksanakan setiap 6 bulan sekali. Namun untuk ulangan harian diserahkan kepada guru kelas masing-masing. Guru A, C dan E sediri mengadakannya setelah selesai satu tema, guru D, F dan G mengadakannya setiap selesai satu subtema, guru B melaksanakan penilaian setiap hari.

Berdasarkan hasil wawancara, semua guru sudah berusaha membuat soal tes berpikir kritis atau HOTS (High Order Thingking Skills), namun 6 guru belum maksimal. Perbandingan soal yang dibuat 6 guru tersebut masih didominasi oleh soal dengan kualitas LOST (Low Order Thingking Skill) sehingga belum mencapai keterampilan berpikir kritis. Sedangkan 1 guru yaitu guru B sudah maksimal karena beliau sudah 
berpengalaman dalam pembuatan soal. Kesulitan yang dialami mayoritas guri ini dikarenakan sulitnya menentukan stimulus dan KKO (Kata Kerja Operasional). Untuk mengatasi masalah tersebut guru melihat contoh soal-soal sebagai bahan referensi. Langkah-langkah dalam pembuatan soal oleh guru pun sangat beragam, ada yang diawali dengan melihat pada materi pembelajaran terlebih dahulu maupun KD atau tujuan pembelajaran terlebih dahulu dilanjutkan dengan membuat kisi-kisi, soal dan kunci jawaban. Setelah siswa menjawab soal, 7 guru mengaku melakukan analisis terhadap hasil jawaban siswa untuk mengetahui siswa mana yang harus melaksanakan perbaikan dan pengayaan. 2 guru menggunakan google form dan 4 lainnya tidak. Sedangkan untuk penggunaan software yang secara khusus tidak ada.

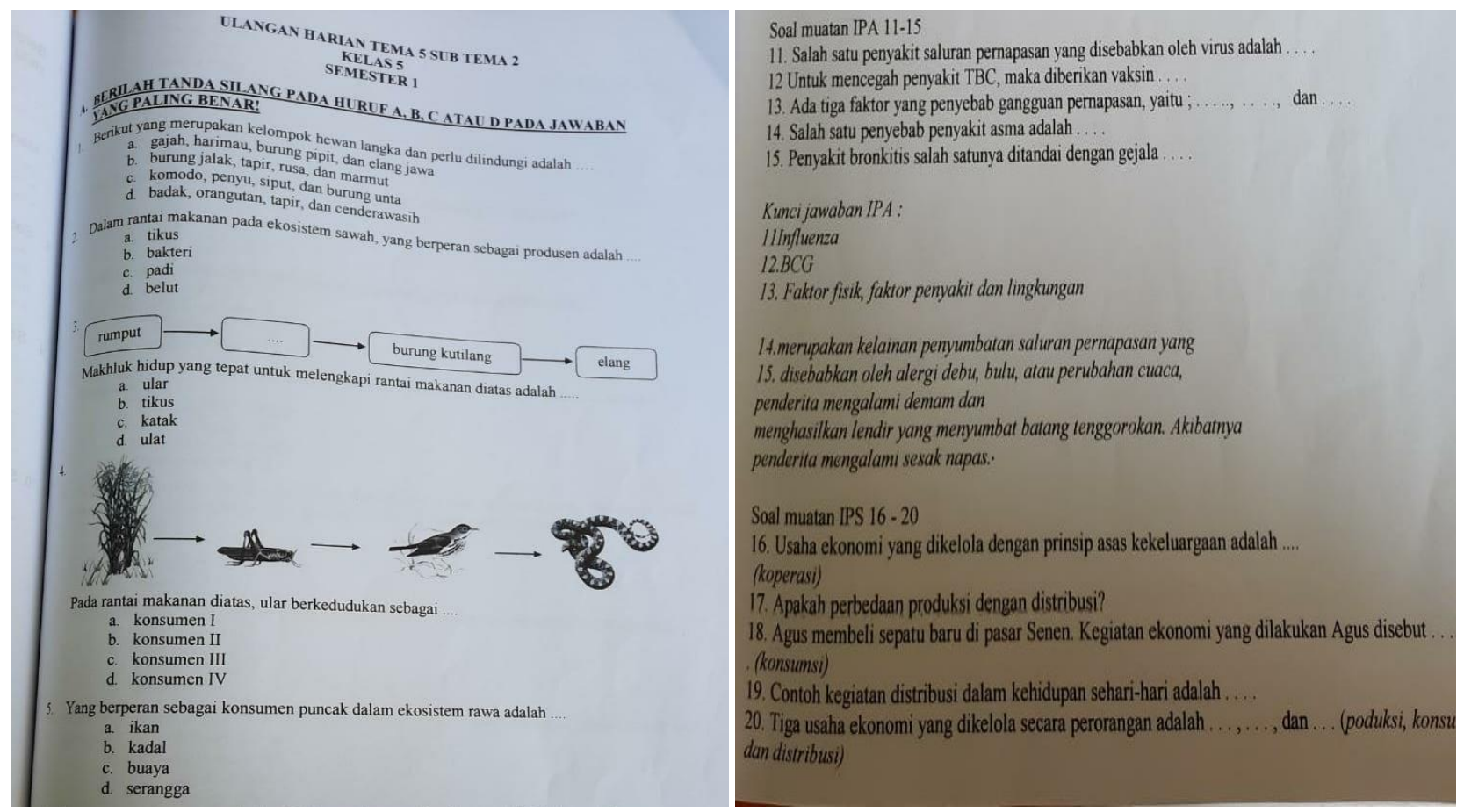

Gambar 2. Contoh soal di sekolah dasar

Berdasarkan kuesioner dan wawancara dapat diketahui bahwa karakteristik guru yang berbeda-beda mempengaruhi pemahamannya terkait penilaian yang diatur dalam kurikulum 2013. Dari hasil kuesioner dan jawaban wawancara terlihat bahwa guru yang sudah pernah mengikuti pelatihan profesi terutama mengenai kurikulum 2013 lebih paham terkait kebijakan yang mengatur penilaian soal tes tertulis dalam kurikulum tersebut. Guru yang belum sama sekali mengikuti pelatihan masih belum terlalu memahaminya. Lamanya mengajar juga dapat mempengaruhi pemahaman guru, untuk guru yang sudah mengajar selama 6 tahun sampai 10 tahun lebih sudah memahami sedangkan yang belum masih kebingunangan. Penilaian dalam kurikulum 2013 lebih holistik dan tegas dibandingkan kurikulum KTSP. Kurikulum 2013 ini mengharapkan supaya guru dapat melakukan penilaian yang dapat melibatkan ketiga ranah domain yaitu kognitif, afektik dan psikomotor secara seimbang sesuai dengan tujuan yang hendak diukur dari masing-masing ranah tersebut (Setiadi, 2016; Tiara \& Sari, 2019).

\section{Pembahasan}

Semua guru merespon positif terhadap kebijakan penerapan soal tes tertulis karena sangat penting untuk mengukur tingkat pengetahuan siswa terhadap materi yang telah disampaikan pada saat pembelajaran. Selain itu juga dapat membuat siswa untuk dapat berpikir secara kritis dan memberikan kesempatan kepada siswa untuk menjawab pertanyaan secara mandiri. Penilaian menggunakan tes sendiri memiliki tujuan untuk memberikan umpan balik (feedback), menentukan pembelajaran selanjutnya, diagnostik kesulitan belajar dan miskonsepsi yang dialami oleh siswa, melihat kemajuan belajar dan sebagai alat evaluasi (Ambussaidi \& Yang, 2019; Backfisch et al., 2020; Monica et al., 2011).

Penilaian menggunakan soal tes tertulis yang ada di masing-masing sekolah ternyata sama yaitu biasanya menggunakan soal tes bentuk pilihan ganda, isian singkat dan uraian. Tes tertulis sendiri merupakan tes soal yang jawabnnya berbentuk tulisan (Chang \& Kang, 2018; Li et al., 2021). Dalam menjawab soal tes tertulis, siswa tidak hanya merespon jawaban dalam bentuk kegiatan menulis tetapi bisa juga dengan mewarnai, memberi tanda, grafik dan lain-lain. Soal tes yang biasa dibuat guru untuk menilai pengetahuan siswa meliputi soal pilihan ganda, essay, menjodohkan, kolom isian dan benar salah (Bazvand et al., 2018; Daniels \& Gierl, 
2017). Bentuk soal ini memudahkan guru dalam melakukan proses standarisasi karena berapapun banyak jumlahnya jawabannya akan tetap sama (Juditya et al., 2020; Zulkifli, 2018). Dengan demikian dapat diketahui bahwa penggunaan soal tes tertulis di sekolah dasar masih kurang bervariasi.

Sejalan dengan itu, ke-5 guru sudah memahami makna dari keterampilan berpikir kritis secara umum namun belum memahami maknanya sec ara khusus dan detail, sedangkan 2 guru lainnya sudah paham. Semua guru juga dapat memahami bahwa keterampilan berpikir kritis erat kaitannya dengan HOTS (High Order Thingking Skills) yang memiliki tingkatan berpikir dari C4 - C6. Berpikir kritis melibatkan seperangkat keterampilan dan disposisi yang dimobilisasi untuk menyelesaikan suatu masalah, mengambil keputusan dan berinteraksi dengan orang lain (Drennan, 2010; Silberman et al., 2021; Yamin et al., 2020). Indikator keterampilan berpikir kritis mencakup berbagai keterampilan seperti analisis, sintesis, pemecahan masalah, inferensi dan evaluasi (Boso et al., 2021; Sapeni \& Said, 2020). Keterampilan ini merupakan bagian dari tingkatan HOTS (Putranta \& Supahar, 2019; Sagala \& Andriani, 2019; Taimur \& Sattar, 2018).

Terkait pengembangan soal semua guru sudah berusaha mengembangkan soal tes tertulis untuk mengukur keterampilan berpikir kritis siswa, namun mayoritas soal yang telah dikembangkan tidak cukup banyak dan masih didominasi oleh soal-soal dengan taraf berpikir rendah. Hal ini dibuktikan dengan contoh soal yang ada,soal jarang sekali diawali dengan stimulus serta pemilihan pertanyaan yang diajukan hanya sebatas pertanyaan untuk menggali ingatan siswa. Kendala yang dialami oleh guru ini dikarenakan sulitnya menentukan KKO (Kata Kerja Operasioal) yang hendak mengukur tingkat berpikir siswa serta sulit dalam memilih stimulus sehingga kadang tidak sesuai dengan pertanyaan yang diajukan kepada siswa. Kreativitas seorang guru dapat menentukan variasi dari stimulus yang digunakan (Pratama \& Retnawati, 2018; Yusoff \& Seman, 2018). Stimulus merupakan hal yang penting dalam menyusun soal-soal bertipe HOTS (Heong et al., 2011; Sagala \& Andriani, 2019). Stimulus ini dapat diambil dari isu-isu global seperti ekonomi, pendidikan, sosial, teknologi, dan kesehatan. Bisa juga diambil dari persoalan di lingkungan sekitar seperti budaya, adat dan kelebihan dari suatu wilayah. Perlu diperhatikan pemilihan stimulus dalam soal hendaknya kontestual dan menarik (Abosalem, 2016; Putranta \& Supahar, 2019).

Berdasarkan langkah-langkah yang dilakukan guru dalam pembuatan soal tidaklah sama, ada guru yang membuat soal dengan menentukan $K D$ dan indikator terlebih dahulu ada juga yang membuat soal diawali dengan langsung berfokus pada tujuan dan materi pembelajaran yang hendak dicapai oleh siswa. Hanya 4 dari 7 guru sekolah dasar yang membuat kisi-kisi soal. Seharusnya soal tes tertulis HOTS dikembangkan melalui berberapa tahapan yang disesuaikan dengan kebutuhan dari penyusun soal (Ibrahim et al., 2020; Johanns et al., 2017). Tahapan-tahapan dalam menyusun soal HOTS yakni 1) menganalisis KD untuk dibuat soal HOTS, 2) Membuat kisi-kisi soal, 3) memilih stimulus yang kontekstual dan menarik bagi siswa ,4) menulis butir soal sesuai dengan kisi-kisi soal, 5) membuat pedoman penskoran (Fanani, 2018; Widana, 2020).

Sejalan dengan itu, setelah mengerjakan soal tes yang diberikan, hasil jawaban siswa hendaknya dianalisis secara akurat supaya kemampuan siswa dapat terukur dengan baik serta dapat mengukur kelayakan soal tes yang telah dibuat (Hassan et al., 2016; Tanudjaya \& Doorman, 2020). Adapun hasil tes yang baik apabila memenuhi aspek validitas dan reliabilitas instrumen, sehingga dapat dipercaya dan layak untuk digunakan (Chan \& Ismail, 2014; Gurel et al., 2015; Segers et al., 2018). Namun kenyataanya di lapangan, walaupun semua guru mengaku melakukan analisis terhadap hasil tes tetapi masih tidak akurat karena cenderung bersifat subjektif. Penggunaan aplikasi khusus untuk menganalisis tidak dilakukan oleh guru dikarenakan kendala waktu yang sangat menyita dan kurang pahamnya penggunaan aplikasi semacam itu.

Di sisi lain, terkait pembelajaran program berbasis ESD sendiri, berdasarkan penelitian hanya 2 guru yang pernah mendengar istilah tersebut, 5 guru lainnya sama sekali belum pernah. Tetapi untuk pelaknasaanya mungkin sudah terealisasikan hanya saja belum maksimal. ESD ini dikenalkan pada bidang pendidikan sebagai pendekatan dalam pembelajaran dalam rangka mendukung program pembangunan berkelanjutan (Clarisa et al., 2020; Putri et al., 2019).. Terdapat beberapa sekolah yang memang sudah menerapkan nilai-nilai ESD, namun pada kenyataannya mereka tidak mengetahui mengenai ESD sama sekali (Clarisa et al., 2020; Listiawati, 2013). Hal tersebut bisa saja disebabkan karena Kurikulum 2013 pada mata Nasional (2010-2014) tidak secara gamblang menyatakan komitmen terhadap ESD, tetapi pendidikan nasional di Indonesia didedikasikan pada aspek pembangunan nasional (Putri et al., 2019). Sehingga konsep tersebut belum banyak dipahami oleh guru. Guru hanya mengetahui pembelajaran yang berbasis lingkungan, sosial dan ekonomi saja belum mengajarkan untuk berkelanjutan di masa yang akan datang. Dengan demikian soal tes berpikir kritis berbasis ESD juga sepertinya minim jumlahnya.

Adapun yang perlu diperbaiki dari soal-soal yang ada di sekolah dasar saat ini yaitu dengan menambahkan jumlah soal tipe HOTS untuk melatih keterampilan berpikir kritis siswa (Ani Rahmawati, Nur Lailatin Nisfah, 2019; Harta et al., 2020). Ke 7 guru tersebut memiliki ide kedepannya dalam mengembangkan soal HOTS yaitu dengan penggunaan stimulus yang lebih bervariasi berupa skema, gambar dan infografis, grafik, diagram dan lain-lain. Stimulus yang disajikan hendaknya menarik dan kontekstual, stimulus ini dapat diambil dari isu-isi global contohnya masalah teknologi dan informasi, sains, ekonomi, kesehatan, pendidikan dan infrastruktur (Fanani, 2018; Ichsan et al., 2019). Hasil dari penelitian ini dapat gunakan sebagai rujukan dalam 
mengetahui kemampuan guru sekolah dasar dalam mengembangkan soal tes berpikir kritis. Adapun keterbatasan dari penelitian ini yaitu belum adanya tindak lanjut dalam rangka meningkatkan kemampuan pedagodik guru terkait penyesunan soal tes berpikir kritis atau tipe HOTS. Sehingga disarankan kepada peneliti lain untuk dapat meneliti hal yang berkaitan dengan kemampuan guru dalam mengembangkan soal tes berpikir kritis berbasis ESD (Education Sustainable Development).

\section{SIMPULAN}

Kemampuan guru dalam mengambangkan soal berpikir kritis atau soal tipe HOTS masih rendah. Para guru perlu diberikan contoh yang tepat mengenai pengembangan soal tes yang dapat menggali kemampuan berpikir kritis. Terkait pengembangan soal tes dengan pembelajaran berbasis ESD dapat dilakukan secara beriringan. Memberikan Pelatihan yang sesuai antara pengembangan pembelajaran ESD dan asesmen yang sesuai. Lingkup tersebut merupakan upaya untuk memperkaya pengetahuannya guru yang perlu banyak pengalaman dalam melihat contoh-contoh soal tes berpikir kritis sebagai referensi.

\section{DAFTAR PUSTAKA}

Abosalem, Y. (2016). Assessment techniques and students' higher-order thinking skills. International Journal of Secondary Education, 4(1), 1-11. https://doi.org/10.11648/j.ijsedu.20160401.11.

Agusti, K. A., Wijaya, A. F. C., \& Tarigan, D. E. (2019). Problem Based Learning dengan Konteks ESD untuk Meningkatkan Keterampilan Berpikir Kritis dan Sustainability Awareness Siswa SMA pada Materi Pemanasan Global. VIII, SNF2019-PE-175-182. https://doi.org/10.21009/03.SNF2019.01.PE.22.

Ambussaidi, I., \& Yang, Y.-F. (2019). The Impact of Mathematics Teacher Quality on Student Achievement in Oman and Taiwan. International Journal of Education and Learning, 1(2), 50-62. https://doi.org/10.31763/ijele.v1i2.39.

Ani Rahmawati, Nur Lailatin Nisfah, S. K. (2019). The Capability Analysis of High Order Thinking Skills (HOTS) on Dynamic Electricity Material in Junior High School. JPPPF: Jurnal Penelitian Dan Pengembangan Pendidikan Fisika, 5(3). https://doi.org/10.21009/1.05211.

Backfisch, I., Lachner, A., Hische, C., Loose, F., \& Scheiter, K. (2020). Professional knowledge or motivation? Investigating the role of teachers' expertise on the quality of technology-enhanced lesson plans. Learning and Instruction, 66. https://doi.org/10.1016/j.learninstruc.2019.101300.

Bazvand, A. D., Khorram, A., \& Mirsalari, S. A. (2018). Establishing an argument-based validity approach for a low-stake test of collocational behavior. Journal of English Language Teaching and Learning, 10(22), 2748.

Boso, C. M., van der Merwe, A. S., \& Gross, J. (2021). Students' and educators' experiences with instructional activities towards critical thinking skills acquisition in a nursing school. International Journal of Africa Nursing Sciences, 14, 100293. https://doi.org/10.1016/j.ijans.2021.100293.

Chan, S. W., \& Ismail, Z. (2014). Developing Statistical Reasoning Assessment Instrument for High School Students in Descriptive Statistics. Procedia - Social and Behavioral Sciences, 116. https://doi.org/10.1016/j.sbspro.2014.01.943.

Chang, H. Il, \& Kang, W. C. (2018). Why do the poor oppose income redistribution? An empirical test on the impacts of nationalism and fatalism. The Social Science Journal, 55(4). https://doi.org/10.1016/j.soscij.2018.05.002.

Clarisa, G., Danawan, A., Muslim, \& Wijaya, A. F. C. (2020). Penerapan Flipped Classroom dalam Konteks ESD untuk Meningkatkan Kemampuan Kognitif dan Membangun Sustainability Awareness Siswa. Journal of Natural Science and Integration, 3(1), 13-25. https://doi.org/10.24014/jnsi.v3i1.8953.

Daniels, L. M., \& Gierl, M. J. (2017). The impact of immediate test score reporting on university students' achievement emotions in the context of computer-based multiple-choice exams. Learning and Instruction, 5(2). https://doi.org/10.1016/j.learninstruc.2017.04.001.

Darmaji, Kurniawan, D. A., Astalini, Lumbantoruan, A., \& Samosir, S. C. (2019). Mobile learning in higher education for the industrial revolution 4.0: Perception and response of physics practicum. In International Journal of Interactive Mobile Technologies (Vol. 13, Issue 9). https://doi.org/10.3991/ijim.v13i09.10948.

Destiniar, Mulbasari, A. S., Fuadiah, N. F., Octaria, D., Ningsih, Y. L., Retta, A. M. R., \& Isroqmi, A. (2020). Pelatihan Penyusunan Soal HOTS untuk Mengambangkan Kemampuan Pedagogik Guru. J-APDIPAMAS (Jurnal Pengabdian Kepada Masyarakat), 4(1), 163-170.

Didham, R. J., \& Ofei-Manu, P. (2020). Adaptive capacity as an educational goal to advance policy for integrating DRR into quality education for sustainable development. International Journal of Disaster Risk Reduction, 47. https://doi.org/10.1016/j.ijdrr.2020.101631.

Drennan, J. (2010). Critical thinking as an outcome of a Master's degree in nursing programme. Journal of 
Advanced Nursing, 66(2), 422-431. https://doi.org/10.1111/j.1365-2648.2009.05170.x.

Fanani, M. Z. (2018). Strategi Pengembangan Soal Higher Order Thinking Skill (HOTS) dalam Kurikulum 2013. Edudeena, 2(1), 57-76. https://doi.org/10.30762/ed.v2i1.582.

Fenanlampir, A., Batlolona, J. R., \& Imelda, I. (2019). The Struggle of Indonesian Students in The Context of TIMSS and PISA Has Not Ended. International Journal of Civil Engineering and Technology, 10(2), 393-406.

Ferrer-Estévez, M., \& Chalmeta, R. (2021). Integrating Sustainable Development Goals in educational institutions. The International Journal of Management Education, 19(2). https://doi.org/10.1016/j.ijme.2021.100494.

Gurel, D. K., Eryilmaz, A., \& McDermott, L. C. (2015). A review and comparison of diagnostic instruments to identify students' misconceptions in science. Eurasia Journal of Mathematics, Science and Technology Education, 11(5), 989-1008. https://doi.org/10.12973/eurasia.2015.1369a.

Handayani, S. L., \& Amirullah, G. (2019). Meningkatkan Pemahaman Guru Sekolah Dasar Melalui Pelatihan Penyusunan Rencana Pelaksanaan Pembelajaran Berbasis Literasi, 4C, PPK dan HOTS. Jurnal SOLMA, 8(1), 14-23. https://doi.org/10.29405/solma.v8i1.2949.

Harta, J., Rasuh, N. T., \& Seriang, A. (2020). Using HOTS-Based Chemistry National Exam Questions to Map the Analytical Abilities of Senior High School Students. Journal of Science Learning, 3(3), 143-148. https://doi.org/10.17509/jsl.v3i3.22387.

Hassan, S. R., Rosli, R., \& Zakaria, E. (2016). The Use of i-Think Map and Questioning to Promote Higher-Order Thinking Skills in Mathematics. Creative Education, 07(07), 1069-1078. https://doi.org/10.4236/ce.2016.77111.

Heong, Y. M., Othman, W. B., Yunos, J. B. M., Kiong, T. T., Hassan, R. Bin, \& Mohamad, M. M. B. (2011). The Level of Marzano Higher Order Thinking Skills among Technical Education Students. International Journal of Social Science and Humanity, 1(2), 121-125. https://doi.org/10.7763/ijssh.2011.v1.20.

Ibrahim, I., Kuswidi, I., \& Arfinanti, N. (2020). Development of a Guide to Preparation of Mathematics Questions Based on Higher Order Thinking Skills and Strengthening Character Education for Middle School Teachers. Jurnal Fourier, 9(1). https://doi.org/10.14421/fourier.2020.91.35-42.

Ichsan, I. Z., Sigit, D. V., Miarsyah, M., Ali, A., Arif, W. P., \& Prayitno, T. A. (2019). HOTS-AEP: Higher order thinking skills from elementary to master students in environmental learning. European Journal of Educational Research, 8(4), 935-942. https://doi.org/10.12973/eu-jer.8.4.935.

Johanns, B., Dinkens, A., \& Moore, J. (2017). A systematic review comparing open-book and closed-book examinations: Evaluating effects on development of critical thinking skills. Nurse Education in Practice, 27, 89-94. https://doi.org/10.1016/j.nepr.2017.08.018.

Juditya, S., Suherman, A., Ma'mun, A., \& Rusdiana, A. (2020). The Basic Movement Skill Test Instrument of Ball Games for Students Aged 13-15 Years. Jurnal Pendidikan Jasmani Dan Olahraga, 5(1). https://doi.org/10.17509/jpjo.v5i1.21447.

Kadir, A. (2015). Menyusun Dan Menganalisis Tes Hasil Belajar. Al-Ta'dib, 8(2), 70-81. https://doi.org/10.31332/atdb.v8i2.411.

Khan, F. M. A., \& Masood, M. (2015). The Effectiveness of an Interactive Multimedia Courseware with Cooperative Mastery Approach in Enhancing Higher Order Thinking Skills in Learning Cellular Respiration. Procedia Social and Behavioral Sciences, 176, 977-984. https://doi.org/10.1016/j.sbspro.2015.01.567.

Kostiainen, E., Ukskoski, T., Ruohotie-Lyhty, M., Kauppinen, M., Kainulainen, J., \& Mäkinen, T. (2018). Meaningful learning in teacher education. Teaching and Teacher Education, 71, 66-77. https://doi.org/10.1016/j.tate.2017.12.009.

Lestari, N. D. (2018). Analisis Penerapan Kurikulum 2013 Dalam Meningkatkan Kualitas Pembelajaran Ekonomi Di Sma Negeri Se-Kota Palembang. Jurnal Neraca: Jurnal Pendidikan Dan Ilmu Ekonomi Akuntansi, 2(1), 68-79. https: //doi.org/10.31851/neraca.v2i1.2190.

Li, F.-Y., Hwang, G.-J., Chen, P.-Y., \& Lin, Y.-J. (2021). Effects of a concept mapping-based two-tier test strategy on students' digital game-based learning performances and behavioral patterns. Computers \& Education, 24. https://doi.org/10.1016/j.compedu.2021.104293.

Lia, L. (2015). Multimedia Interaktif Sebagai Salah Satu Alternatif Pembelajaran dalam Bidang Pendidikan Sains. Jurnal Inovasi Dan Pembelajaran Fisika, 2(2), 132-140. https://doi.org/10.36706/jipf.v2i2.2614.

Listiawati, N. (2013). Pelaksanaan Pendidikan untuk Pembangunan Berkelanjutan oleh Beberapa Lembaga. Jurnal Pendidikan Dan Kebudayaan, 19(3), 430-450. https://doi.org/10.24832/jpnk.v19i3.302.

Miles, Huberman, \& Saldana. (2014). Qualitative Data Analysis. In A Methods Sourcebooks, Edition 3. SAGE Publication, Inc.

Monica, Gorghiu, Bîzoi, \& Marra. (2011). a Modern Instrument Used in Teachers ' Training Process. Procedia Computer Science, 3(1), 563-567. https://doi.org/10.1016/j.procs.2010.12.09.

Nada, I., Utaminingsih, S., \& Ardianti, S. D. (2018). Penerapan Model Open Ended Problems Berbantuan Cd Pembelajaran Untuk Meningkatkan Kemampuan Berpikir Kreatif Siswa Kelas Iv Sd 1 Golantepus. Jurnal Pendidikan Sekolah Dasar, 4(2), 216. https://doi.org/10.30870/jpsd.v4i2.3856.

Narayanan, S., \& Adithan, M. (2015). Analysis Of Question Papers In Engineering Courses With Respect To Hots 
(Higher Order Thinking Skills). American Journal of Engineering Education (AJEE), 6(1), 1-10. https://doi.org/10.19030/ajee.v6i1.9247.

Nugrahanto, S., \& Zuchdi, D. (2019). Indonesia PISA Result and Impact on The Reading Learning Program in Indonesia. International Conference on Interdisciplinary Language, Literature and Education (ICILLE 2018), 297(0), 373-377. https://doi.org/10.2991/icille-18.2019.77.

Oh, H.-J., \& Park, J.-K. (2017). The Development and Application of Education for Sustainable Development (ESD) Program related to Creative-Experience Activity for Elementary School Students. Journal of Korean Elementary Science Education, 36(4), 316-330. https://doi.org/10.15267/keses.2017.36.4.316.

Ortega-Sánchez, M., Moñino, A., Bergillos, R. J., Magaña, P., \& Clavero, M. (2018). Confronting learning challenges in the field of maritime and coastal engineering: Towards an educational methodology for sustainable development. Journal of Cleaner Production, 171. https://doi.org/10.1016/j.jclepro.2017.10.049.

Pearce, H., Hudders, L., \& Sompel, D. Van de. (2020). Young energy savers: Exploring the role of parents, peers, media and schools in saving energy among children in Belgium. Energy Research \& Social Science, 63. https://doi.org/10.1016/j.erss.2019.101392.

Pratama, G. S., \& Retnawati, H. (2018). Urgency of Higher Order Thinking Skills (HOTS) Content Analysis in Mathematics Textbook. Journal of Physics: Conference Series, 1097(1). https://doi.org/10.1088/17426596/1097/1/012147.

Psaradakis, Z., \& Vávra, M. (2020). Normality tests for dependent data: large-sample and bootstrap approaches. Communications in Statistics: Simulation and Computation, 49(2), 283-304. https://doi.org/10.1080/03610918.2018.1485941.

Putra, I. G. D., \& Sujana. (2020). Hasil belajar IPS menggunakan Kolaborasi Model Discovery Learning Berbasis Media Animasi. Journal of Educational Technology, 4, 103-109. https://doi.org/10.23887/jet.v4i2.25099.

Putranta, H., \& Supahar. (2019). Synthesis of the Cognitive Aspects' Science Literacy and Higher Order Thinking Skills (HOTS) in Chapter Momentum and Impulse. Journal of Physics: Conference Series, 1397(1). https://doi.org/10.1088/1742-6596/1397/1/012014.

Putri, T., Suwarma, I. R., Danawan, A., \& Wijaya, A. F. C. (2019). Penerapan Model Real World Situation Problem Based Learning Menggunakan Konteks Esd Dalam Meningkatkan Sustainability Awareness Siswa Di Kelas X. VIII, SNF2019-PE-419-428. https://doi.org/10.21009/03.snf2019.01.pe.53.

Rahaju, E. B., Fardah, D. K., Prandoyo, W., \& Ismail. (2020). Kemampuan Guru-Guru Matematika SMP Kabupaten Ponorogo dalam Mengembangkan Soal Berpikir Tingkat Tinggi. Jurnal Pendidikan Matematika Raflesia, 05(01), 75-81. https://doi.org/10.33449/jpmr.v5i1.10640.

Rahmat, A. A., Hamdu, G., Nur, E., \& Muiz, D. A. (2020). Pengembangan Soal Tes Tertulis Berbasis STEM dengan Pemodelan RASCH di Sekolah Dasar. Metodik Didaktik: Jurnal Pendidikan Ke-SD-An, 16(1), $29-40$. https://doi.org/10.17509/md.v16i1.25099.

Sagala, P. N., \& Andriani, A. (2019). Development of Higher-Order Thinking Skills (HOTS) Questions of Probability Theory Subject Based on Bloom's Taxonomy. Journal of Physics: Conference Series, 1188(1). https://doi.org/10.1088/1742-6596/1188/1/012025.

Sapeni, M. A.-A. R., \& Said, S. (2020). The effectiveness of case-based learning in increasing critical thinking of nursing students: A literature review. Enfermería Clínica, 30(2). https://doi.org/10.1016/j.enfcli.2019.07.073.

Segers, M., Martens, R., \& Bossche, P. Van den. (2018). Understanding how a case-based assessment instrument influences student teachers' learning approaches. Teaching and Teacher Education, 4(3). https://doi.org/10.1016/j.tate.2008.02.022.

Setiadi, H. (2016). Pelaksanaan penilaian pada Kurikulum 2013. Jurnal Penelitian Dan Evaluasi Pendidikan, 20(2), 166-178. https://doi.org/10.21831/pep.v20i2.7173.

Silberman, D., Carpenter, R., Takemoto, J. K., \& Coyne, L. (2021). The impact of team-based learning on the critical thinking skills of pharmacy students. Currents in Pharmacy Teaching and Learning, 13(2), 116-121. https://doi.org/10.1016/j.cptl.2020.09.008.

Subagia, I. W., \& Wiratma, I. G. L. (2016). Profil Penilaian Hasil Belajar Siswa Berdasarkan Kurikulum 2013. JPI (Jurnal Pendidikan Indonesia), 5(1), 39-54. https://doi.org/10.23887/jpi-undiksha.v5i1.8293.

Suparmi, N. W. (2019). Hasil Belajar Pemahaman Konsep Dan Berpikir Kreatif Siswa Dalam Pembelajaran Inkuiri Bebas Dan Inkuiri Terbimbing. Journal of Education Technology, 2(4), 192. https://doi.org/10.23887/jet.v2i4.16548.

Suratmi, Laihat, \& Asnimar. (2020). Development of Assessment Instruments Based on Higher Order Thinking Skills (HOTS) for Elementary School Students. Jurnal Pendidikan Sekolah Dasar (JPsd), 6(1), 199-211. https://doi.org/10.30870/jpsd.v6i2.7356.

Taimur, S., \& Sattar, H. (2018). Education for Sustainable Development and Critical Thinking Competency. Springer Nature Switzerland AG, September, 1-11. https://doi.org/10.1007/978-3-319-69902-8_64-1.

Tanudjaya, C. P., \& Doorman, M. (2020). Examining higher order thinking in Indonesian lower secondary mathematics classrooms. Journal on Mathematics Education, 11(2), 277-300. 
https://doi.org/10.22342/jme.11.2.11000.277-300.

Tiara, S. K., \& Sari, E. Y. (2019). Analisis Teknik Penilaian Sikap Sosial Siswa Dalam Penerapan Kurikulum 2013 Di Sdn 1 Watulimo. EduHumaniora / Jurnal Pendidikan Dasar Kampus Cibiru, 11(1), 21. https://doi.org/10.17509/eh.v11i1.11905.

Widana, I. W. (2020). Pengaruh Pemahaman Konsep Asemen HOTS terhadap Kemampuan Guru Matematika SMA/SMK Menyusun Soal HOTS. Jurnal Emasains: Jurnal Edukasi Matematika Dan Sains, 9(1), 66-75. https://doi.org/10.5281/zenodo.3743923.

Wijayanti, W., \& Christian Relmasira, S. (2019). Pengembangan Media PowerPoint IPA Untuk Siswa Kelas IV SD Negeri Samirono. Jurnal Penelitian Dan Pengembangan Pendidikan, 3(2), 77. https://doi.org/10.23887/jppp.v3i2.17381.

Winarti, Hairida, \& Lestari, I. (2021). Deskripsi Kemampuan Guru Membuat Soal Berdasarkan pada Kurikulum 2013 di Sekolah Menengah Atas Kabupaten Landak. Jurnal Ilmiah Wahana Pendidikan, 7(2), 108-115. https://doi.org/10.5281/zenodo.3737983.

Wulandari, A. (2020). Implementation of the 2013 Curriculum Based on a Scientific Approach (Case Study at SD Cluster II Kintamani). International Journal of Elementary Education, 4(3), 422. https://doi.org/10.23887/ijee.v4i3.28172.

Yamin, M., Saputra, A., \& Deswila, N. (2020). Enhancing Critical Thinking in Analyzing Short Story "The Lazy Jack" Viewed from Identity Theory. Indonesian Journal on Learning and Advanced Education (IJOLAE), 3(1), 30-39. https://doi.org/10.23917/ijolae.v3i1.9948.

Yuliani, W. (2018). Metode Penelitian Deskriptif Kualitatif dalam Perspektif Bimbingan dan Konseling. Quanta, 2(2), 83-91. https://doi.org/10.22460/q.v1i1p1-10.497.

Yusoff, W. M. W., \& Seman, S. C. (2018). Teachers' Knowledge of Higher Order Thinking and Questioning Skills: A Case Study at a Primary School in Terengganu, Malaysia. International Journal of Academic Research in Progressive Education and Development, 7(2), 45-63. https://doi.org/10.6007/ijarped/v7-i2/4120.

Yusuf, M. (2017). Asesmen dan Evaluasi Pendidikan: Pilar Penyedia Informasi dan Kegiatan Pengendalian Mutu Pendidikan. Kencana.

Zulkifli, M. (2018). Analisis Bentuk Evaluasi Kurikulum 2013 Mata Pelajaran Bahasa Arab di MI. Al-Madrasah: Jurnal Pendidikan Madrasah Ibtidaiyah, 2(2), 125-143. https://doi.org/10.35931/am.v0i0.29. 